University of New Orleans

ScholarWorks@UNO

3-1997

\title{
Taking a Perspective: Hawthorne's Concept of Language and Nineteenth-Century Language Theory
}

\author{
Patricia M. Roger \\ University of New Orleans, pmroger@uno.edu
}

Follow this and additional works at: https://scholarworks.uno.edu/engl_facpubs

Part of the Literature in English, North America Commons

\section{Recommended Citation}

Roger, Patricia M. "Taking a Perspective: Hawthorne's Concept of Language and Nineteenth-Century Language Theory." Nineteenth-Century Literature 51.4 (1997): 433-454.

This Article is brought to you for free and open access by the Department of English and Foreign Languages at ScholarWorks@UNO. It has been accepted for inclusion in English Faculty Publications by an authorized administrator of ScholarWorks@UNO. For more information, please contact scholarworks@uno.edu. 


\title{
Taking a Perspective: Hawthorne's Concept of Language and Nineteenth-Century Language Theory
}

\author{
PATRICIA M. ROGER
}

\section{“ $O$}

$\mathrm{H}$, was there not, from the first, more poison in thy nature than in mine?" cries Beatrice at the end of "Rappaccini's Daughter." The poison in her nature is literal, and while the story indicates that her contact with Giovanni has transmitted this poison to him, her final words nevertheless suggest that Giovanni was poisoned by an even more deadly, figurative venom from the very start. Throughout the story, as in his Notebooks and much of his fiction, Hawthorne explores the complex relations between literal and figurative meanings and shows the ways in which one's perspective determines the interpretation of those relations. The issue of whether and how language might correspond to physical and spiritual "facts" was the subject of much debate in the mid nineteenth century. Recently, many critics have been struck by the almost postmodern indeterminacy of Hawthorne's fiction. Two opposing theoretical positions have emerged to account for this indeterminacy-the deconstructionist view as

(C) 1997 by The Regents of the University of California

1 "Rappaccini's Daughter," in Mosses from an Old Manse, ed. William Charvat, Roy Harvey Pearce, and Claude M. Simpson, vol. 10 of The Centenary Edition of the Works of Nathaniel Hawthorne (Columbus: Ohio State Univ. Press, 1974), p. 127. 
exemplified by J. Hillis Miller's analysis of "The Minister's Black Veil," and the more historical and political view that Jonathan Arac takes in "The Politics of The Scarlet Letter." Miller argues that "The Minister's Black Veil" "is the unveiling of the possibility of the impossibility of unveiling." ${ }^{2}$ The veil makes us want to see what is behind it, but, Miller asks, is not the face behind the veil yet another veil? Miller's reading of the story shows the affinity of deconstructionist theory to Hawthorne's explorations of the possibility (or impossibility) of meaning. ${ }^{3}$ Arac, in contrast, claims that "Hawthorne's own authorial meaning establishes an 'indeterminacy' that is not merely a modern critical aberration." ${ }^{4}$ Arac argues that the indeterminacy of the scarlet letter is connected to a politics that avoided action on the slavery issue.

I argue that although Hawthorne's indeterminacy may invite a deconstructionist analysis, it is a product of his historical context, not ours. Even though Hawthorne may have been exploring questions similar to those of Derrida and de Man, for example, he does not reach their sorts of conclusions about the relation of language and "truth." The crucial difference between the American literary and intellectual world of the mid nineteenth century and that of the late twentieth century is the predominance in the nineteenth century of a belief in a "center or origin," a belief in God, which provides for the possibility

2 Hawthorne and History: Defacing It (Cambridge, Mass.: Basil Blackwell, 1991 ), p. 51 .

3 For other analyses of Hawthorne's work using post-structuralist theories of indeterminacy and allegory, see, for example, Millicent Bell, "The Obliquity of Signs: The Scarlet Letter," Massachusetts Review, 23 (1982), 9-26; Dennis Foster, "The Embroidered Sin: Confessional Evasion in The Scarlet Letter," Criticism, 25 (1983), 141 -63; John Dolis, "Hawthorne's Letter," Notebooks in Cultural Analysis, 1 (1984), 103-23; Allan Gardner Lloyd-Smith, Eve Tempted: Writing and Sexuality in Hawthorne's Fiction (Totowa, N.J.: Barnes and Noble, 1983); Christine Brooke-Rose, "A for But: 'The Custom-House' in Hawthorne's The Scarlet Letter," Word Ẽ Image, 3 (1987), 143-55; Beverly Haviland, "The Sin of Synecdoche: Hawthorne's Allegory against Symbolism in 'Rappaccini's Daughter,'” Texas Studies in Literature and Language, 29 (1987), 278-301; Deborah L. Jones, "Hawthorne's Post-Platonic Paradise: The Inversion of Allegory in Rappaccini's Daughter," The Journal of Narrative Technique, 18 (1988), 153-69; Richard Hull, “'I Have no Heavenly Father': Foucauldian Epistemes in The Scarlet Letter," American Transcendental Quarterly, n.s. 3 (1989), 3o9-23.

4 "The Politics of The Scarlet Letter," in Ideology and Classic American Literature, ed. Sacvan Bercovitch and Myra Jehlen (Cambridge: Cambridge Univ. Press, 1986), p. 261. 
of stable meaning. ${ }^{5}$ On the other hand Arac's view that "everything is connected with the political" (p. 262) can also be limiting unless we recognize that the political perspective is one among many. One could argue that "everything is connected with" the philosophical, for example, or with the theological. Although, as Arac argues, indeterminacy of meaning in Hawthorne's fiction certainly may be connected to a politics of avoidance, I will here suggest that Hawthorne's indeterminacy more directly arises out of the linguistic and philosophical issues being debated by his contemporaries.

Some recent critics have called attention to the importance of the study of language in the United States during the nineteenth century. Philip F. Gura has studied the relation of the theological debates about language to the literature of the American Renaissance. He finds that the theological issues raised by the Trinitarian/Unitarian debates appear in the literature of the American Renaissance and give the writing its ambiguity, but he does not focus specifically on the ways in which Hawthorne explores in his writing the ideas about language current at the time. ${ }^{6}$ Thomas Gustafson has examined the renewal in the United States during the period between the Revolution and the Civil War of the tradition connecting political disorders to the corruption of language. He includes Hawthorne among other writers of the period who were trying to reform people's understanding of the potentials and liabilities of language. ${ }^{7}$ Michael P. Kramer has studied the ways in which, as he says, language was "imagined" during this period in the United States. In his discussion of Hawthorne, Kramer focuses particularly on

${ }^{5}$ Derrida writes: "This moment [to which he alludes at the beginning of his essay] was that in which language invaded the universal problematic; that in which, in the absence of a center or origin, everything became discourse ... when everything became a system where the central signified, the original or transcendental signified, is never absolutely present outside a system of differences" ("Structure, Sign, and Play in the Discourse of the Human Sciences," in The Languages of Criticism and the Sciences of Man: The Structuralist Controversy, ed. Richard Macksey and Eugenio Donato [Baltimore: Johns Hopkins Press, 197o], p. 249).

${ }^{6}$ See The Wisdom of Words: Language, Theology, and Literature in the New England Renaissance (Middletown, Conn.: Wesleyan Univ. Press, 1981).

${ }^{7}$ See Representative Words: Politics, Literature, and the American Language, I776-1865 (Cambridge: Cambridge Univ. Press, 1992). 
the capability of language for communication and on the distinctions between private and public discourse. He argues that Hawthorne finds a gap between thoughts and words usually made wider by the division between private and public spheres. ${ }^{8}$ While Kramer links Hawthorne to the empiricists, I find that Hawthorne's attitude toward language is more ambivalent than Kramer indicates. While Hawthorne doubts that language connects nature and spirit directly, he explores the possibilities of different kinds of relations among nature, spirit, and language.

In this essay I combine a historical investigation of language study in the nineteenth century with a close reading of the texts in order to examine the various relations between literal and figurative meanings in the text as well as the influence of the perspectives of the various characters and the narrators on their interpretations of these meanings. I find that the characteristic ambiguity or indeterminacy of Hawthorne's writing arises, at least in part, from his exploration of the linguistic and philosophical issues debated by his contemporaries. Hawthorne responds to these issues by experimenting with possible relations between literal and figurative meanings and with the role played by perspective in determining these meanings. In addition, my approach reveals major differences as well as some similarities between the various attitudes toward language current in the mid nineteenth century and those current today. In order to show the interactions between Hawthorne's writing and the context of mid-nineteenth-century language study, I first briefly outline this context; then, using examples from his Notebooks, I describe Hawthorne's concept of language; and finally, using "Rappaccini's Daughter" as an example, I show how in his fiction Hawthorne experiments with the language theories of his contemporaries.

\section{e}

Speculation about language in the United States during the nineteenth century was extremely varied; it in-

8 See Imagining Language in America: From the Revolution to the Civil War (Princeton: Princeton Univ. Press, 1992). 
cluded theological, philosophical, political, and pedagogical issues. Two dominant points of view were what I call the "spiritual" view and the empirical view. The "spiritual" view accepted God's word as the Truth, which He could communicate to us; the empirical view considered language an imperfect medium for expressing truth because of the arbitrary connection between words and their referents. Although these two views seem contradictory, many nineteenth-century theorists combined them in various ways. For example, in the theological debates of the 1820 s and 183 os about scriptural exegesis, the Trinitarians argued for a figurative reading of scripture while the Unitarians favored an empirical reading, verifying what they read in the Bible by their observations of the world. These debates led to questions about the ways in which language was related to the material world, to human consciousness, and to spiritual truth. ${ }^{9}$ The deciphering of the Egyptian hieroglyphics in the 1820 by Jean-François Champollion also stirred debate about language. According to John T. Irwin, two opposing interpretations of the deciphering emerged: the scientific view that the development of Egyptian writing from the figurative to the phonetic was progressive, and the metaphysical view that this development was a corruption of a simpler, purer state. ${ }^{10}$ These two views clearly correspond to the empirical and "spiritual" perspectives on the nature of language. The debates about language led to movements to reform language in order to make it more clear and/or to reform people in order to make them use language more

9 See Sampson Reed, Observations on the Growth of the Mind (Boston: Cummings, Hilliard, 1826); Andrews Norton, A Statement of Reasons for Not Believing the Doctrines of Trinitarians Respecting the Nature of God and the Person of Christ (Boston: Wells and Lilly, 1819); Moses Stuart, Miscellanies (Andover: Allen, Morrill, and Wardwell, 1846); and James Marsh, Selected Works of James Marsh, 3 vols. (Delmar, N.Y.: Scholars Facsimiles and Reprints, 1976). In addition to these debates about the nature of language during the nineteenth century, a number of people, including Noah Webster, James Fenimore Cooper, and Edward Everett, advocated establishing a distinctly "American" English as opposed to the more aristocratic British version. This movement was somewhat counter to the predominant belief that all languages have one origin, because it isolated American English in order to unify the nation and give it a separate identity. For discussions of the political dimension of nineteenth-century language study, see Kramer, Imagining Language in America; Gustafson, Representative Words; and David Simpson, The Politics of American English, 1776-1850 (New York: Oxford Univ. Press, 1986).

${ }^{10}$ See American Hieroglyphics: The Symbol of the Egyptian Hieroglyphics in the American Renaissance (New Haven: Yale Univ. Press, 1980), pp. 4-10. 
honestly and clearly. The reform movements had elements of both spiritual and empirical views.

The Transcendentalists, including Emerson, Thoreau, Rowland Gibson Hazard, and Elizabeth Peabody (Hawthorne's sister-in-law, who also sponsored the Hungarian physician and language theorist Charles Kraitsir), advocated the "spiritual" view in their theories about the nature of language. They proposed that by recognizing the correspondences between nature and spirit and the way in which language connects nature to spirit, we would see the unity of all things. Most believed that all languages developed from a single language, and they often advocated reforming language so that the original connection between word and thing would be made clear. ${ }^{11}$ Hawthorne often seems to be testing such Transcendentalist views of language in his writing.

In contrast to the Transcendentalists, the empiricists, following Locke, argued against theories that posit language as a mediator between nature and spirit. For them language was an arbitrary system, apart from both the natural and spiritual worlds. In the United States during the mid nineteenth century perhaps the chief proponent of the empiricist view was Alexander Bryan Johnson, a banker who gave public lectures on language. In his Treatise on Language $\left(183_{6}\right)$ he works to convince his audience to stop interpreting nature by language and instead to interpret language by nature. He argues that we must understand that nature is prior to language: "we must contemplate creation apart from words." ${ }^{12} \mathrm{He}$ urges his audience to rely on experience instead of language to interpret life, because "language implies a oneness to which nature conforms not in all cases" (p. 55). He points out that words refer to groups of things

11 See Emerson, Nature, in Essays and Lectures, ed. Joel Porte (New York: Library of America, 1983); Thoreau, Walden, ed. J. Lyndon Shanley (Princeton: Princeton Univ. Press, 1971 ); Elizabeth P. Peabody, "Language," in Aesthetic Papers (1849), ed. Peabody (Boston: Peabody, 1849), pp. 214-24; Charles Kraitsir, Significance of the Alphabet (Boston: E. P. Peabody, 1846) and Glossology: Being a Treatise on the Nature of Language and on the Language of Nature (New York: G. P. Putnam, 1852); and Rowland Gibson Hazard, Essay on Language, and Other Essays and Addresses, ed. Caroline Hazard (Boston: Houghton Mifflin, 1889).

12 Alexander Bryan Johnson, A Treatise on Language, ed. David Rynin (1836; rpt. Berkeley and Los Angeles: Univ. of California Press, 1947), p. 47. 
rather than to specific "existences," causing us to "attribute to nature the generality which belongs to language" (p. 115). For Johnson language is a human invention; it does not mediate between nature and spirit. He emphasizes the limitations of language, arguing that "the meaning of a word varies with its application" (p. 1 1 2) and encouraging his audience "to regard words as merely the names of things" (p. 54). Johnson is primarily interested in reforming people's attitudes toward language so that they will see its limitations. As the Notebooks indicate, Hawthorne, like Johnson, recognizes the limitations of language for describing accurately the objects and operations of nature; unlike Johnson, he also believes that language does somehow participate in relating nature to spirit.

The theories of Horace Bushnell, Congregationalist minister and theologian and a contemporary of Emerson and Hawthorne, are perhaps closest to Hawthorne's attitudes toward language. Although Bushnell has a "theory of correspondences" similar to that of Emerson, he emphasizes the "mystery" of the correspondence:

All things out of sense get their names in language through signs and objects in sense that have some mysterious correspondence or analogy, by which they are prepared beforehand to serve as signs or vehicles of the spiritual things to be expressed. ${ }^{13}$

Hawthorne, too, in many of his Notebooks entries describing natural scenes, seems to find mysterious relations among what Bushnell calls "things out of sense," "signs and objects in sense," and their names in language.

Bushnell argues that words of thought or spirit are "inexact" and that "they always affirm something which is false, or contrary to the truth intended. They impute form to that which really is out of form. They are related to the truth, only as form to spirit" (God in Christ, p. 48). In other words, we can only express spirit or emotion in material terms, which are necessarily inexact or false because spirit and emotion are nonmaterial.

${ }^{13}$ Horace Bushnell, God in Christ: Three Discourses, Delvvered at New Haven, Cambridge, and Andover, with a Preliminary Dissertation on Language (Hartford: Brown and Parsons, 1849), pp. $25-26$. 
Thus, though Bushnell, unlike Johnson, sees an analogy between nature and spirit, he also believes that the analogy is always inexact. For Bushnell, then, language mediates between spirit and nature, but not directly, as Emerson indicates in $\mathrm{Na}$ ture. Again unlike Johnson, Bushnell does not view language as external to nature and therefore merely arbitrary. In fact, he conceives of the relations among nature, spirit, and human consciousness in terms of a language. He writes:

There is a logos in the forms of things, by which they are prepared to serve as types or images of what is inmost in our souls; and then there is a logos also of construction in the relations of space, the position, qualities, connections, and predicates of things, by which they are framed into grammar. In one word, the outer world, which envelops our being, is itself language, the power of all language. (God in Christ, p. 3o)

Bushnell sounds oddly post-structuralist here, positing a world constructed not only of types but of a grammar. Still, his theory of language is different from that of modern theorists, centered as it is in a belief in the power of God, who, he writes, "stands EXPRESSED every where" (p. 3o). Hawthorne's experiments with the idea that language connects nature and spirit seem to have led him to conclusions similar to Bushnell's that language does connect the natural and the spiritual but that the connection is not necessarily direct and clear.

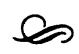

Although Hawthorne did not write specifically about the nature of language, as many of his contemporaries did, his Notebooks are full of explorations of its limitations and capabilities. He often experiments with the idea that language can reveal a correspondence between nature and spirit. Although he often complains that language cannot describe a scene accurately or convey his own impressions truthfully, he also frequently indicates the possibilities that language has to convey meaning, particularly in his notes of what he calls "lit- 
eral pictures of figurative expressions." 14 These "literal pictures" often become the germs of his tales, such as the "heart of stone" in "Ethan Brand." The "literal pictures" allow him to explore relations between literal and figurative meaning and between the literal and the physical and the figurative and the spiritual. Hawthorne refers to the importance of perspective in his Notebooks, primarily in the literal sense of what he can see when he stands in a certain spot but also figuratively in terms of perspective in time, as for example what he can remember. He also, of course, experiments with the perspectives of his characters and his narrators in his fiction.

Particularly in his American Notebooks, which include many detailed descriptions of natural scenes, but in the English Notebooks and the French and Italian Notebooks as well, Hawthorne tests Emerson's theory of correspondences between natural and spiritual "facts." Emerson begins his chapter on "Language" in $\mathrm{Na}$ ture by asserting the relation of language to nature and spirit:

1. Words are signs of natural facts.

2. Particular natural facts are symbols of particular spiritual facts.

3. Nature is the symbol of spirit. (Nature, p. 20)

Emerson maintains that by tracing words back to their roots and by studying nature for its symbolic meanings we can see the correspondences between words, things, and spiritual ideas. Hawthorne follows Emerson's plan in many of his Notebooks entries. For example, in a description of Hudson's Cave, Hawthorne notes a correspondence between a natural scene and human emotion. He compares the cave to "a heart that has been rent asunder by a torrent of passion, which has raged and roared, and left its ineffaceable traces; though now there is but a little rill of feeling at the bottom" (American Notebooks, p. 125). He finds a correspondence between nature's "emotion" and human emotions and explores the ways in which language enters into this correspondence. His description begins with a comparison of the cave to a human heart figuratively "rent asunder

14 The American Notebooks, ed. Claude M. Simpson, vol. 8 of The Centenary Edition (Columbus: Ohio State Univ. Press, 1972), p. 254. 
by a torrent of passion." The "torrent" is both figurative in terms of passion and literal in terms of the stream, which both literally and figuratively "raged and roared." Both figurative passion and literal stream leave "ineffaceable traces" in heart and cave. The "rill" is both a literal tiny stream and a figurative "rill of feeling." In this passage the literal and figurative meanings of the expressions seem clearly to correspond and to indicate a relation between the cave and the heart.

In other passages, however, Hawthorne indicates that a possible correspondence is less clear. His description of the waterfall at Hudson's Cave indicates an initial analogy between the scene and the possibility of understanding spiritual truth:

The water dashed down in a misty cascade, through what looked like the portal of some infernal, subterranean structure; and far within this portal we could see the mist, and the falling water; and it looked as if, but for these obstructions of view, we might have had a deeper insight into a gloomy region.

(American Notebooks, p. 116)

The scene for Hawthorne seems to conceal a secret, simultaneously inviting our view and obstructing it, as nature seems to offer an "insight" into spiritual truth yet to block our view at the same time.

After exploring the idea that nature and spirit correspond and that by studying nature we can understand spiritual truth, Hawthorne ultimately concludes that although we can find correspondences between nature and spirit, they are not always direct and clear; studying nature does not lead to a direct understanding of spiritual truth but rather to an understanding that this "truth" is more complex than any theory of correspondences can indicate.

Further, Hawthorne does not see language as mediating directly between nature and spirit, as Emerson indicates in $\mathrm{Na}$ ture. Hawthorne frequently complains in his notebooks of the impossibility of describing a scene accurately or of conveying his impressions in words. For example, he says that "it is in vain for me to attempt to describe the autumnal brilliancies" of Walden Pond; "impossible to give an idea of the roughness of these rocky shores" at the Isles of Shoals; and in his notebook 
description of the effect of moonlight in a room, made famous in "The Custom-House," he writes that he "cannot in any measure express it" (American Notebooks, pp. 395, 536, 283). These remarks might be taken as examples of what some scholars have claimed was Hawthorne's characteristic diffidence; however, he does not focus on his own inadequacy to use language powerfully but on the inability of language to describe the effect he perceives.

Hawthorne's Notebooks show him arriving at conclusions somewhere between Johnson and Bushnell. Like Johnson, in these entries Hawthorne focuses on the limitation of language to describe accurately; yet, because he continues to describe instances in which he perceives a connection between a natural scene and a spiritual insight, he must believe, like Bushnell, that physical things have a "mysterious correspondence or analogy" to spiritual things and that language may indicate the correspondence. For example, in describing the effects of Walden Pond's "autumnal brilliancies" Hawthorne observes that the colors of the leaves in autumn are soothing rather than exciting. He wonders whether this effect is more "a moral effect, or a physical one operating merely on the eye" (American Notebooks, p. 394), questioning the possibility of a correspondence between moral and physical effects. After trying to put into words the effect of the scene on his consciousness and apparently thinking he has not captured it, he suggests a metaphor comparing the "gaily-clad trees" to "young damsels . . . in a funeral procession ... go[ing] sadly along with their purple, and scarlet, and golden garments trailing over the withering grass" (American Notebooks, pp. 394-95). He compares the scene at Walden Pond to another physical scene presumably to convey more clearly by the metaphor the somber beauty he perceives in the autumn leaves. The metaphor of the damsels in a funeral procession is, of course, only one of a number of metaphors he could have used, and it both augments and limits his description of the effect of the leaves. He has added the image of the damsels sadly walking in gowns of autumn colors, and he has limited his description of the leaves by attaching to it the image of the young girls. Hawthorne concludes that he cannot use words to connect directly the moral or spiritual meaning of the 
scene to the scene itself. Instead he seems to find both that language often cannot directly express the spiritual meanings of physical things and that words often have the tendency to create unforeseen possibilities for meaning.

Hawthorne is drawn to instances in which language seems to reveal some kind of relation between natural and spiritual "facts." In these cases, however, he often indicates that language may be creating rather than revealing relations between nature and spirit. For example, in his American Notebooks Hawthorne notes three examples of figurative expressions pictured literally:

To make literal pictures of figurative expressions;-for instance, he burst into tears-a man suddenly turned into a shower of briny drops. An explosion of laughter-a man blowing up, and his fragments flying about on all sides. He cast his eyes upon the ground-a man standing eyeless, with his eyes on the ground, staring up at him in wonderment \&c \&c \&c. （p. 254）

By emphasizing the literal aspect of the words, Hawthorne brings these "dead" metaphors back to life and reveals the complex, often strange relation between the literal and the figurative that he indicates language may create rather than merely express.

Hawthorne records other literal figures throughout his Notebooks. He usually notes expressions in which the literal aspect has been forgotten, for the most part, and expressions that are strange or fantastic - "to have ice in one's blood" (American Notebooks, p. 184), to "literally eat [someone's] heart" (p. 283)as if he is fascinated by the strange, fantastic, and often violent quality of many common figurative expressions. He notes, for example, that "people who write about themselves and their feelings, as Byron did, may be said to serve up their own hearts, duly spiced, and with brain-sauce out of their own heads, as a repast for the public" (p. 253). ${ }^{15}$ Aside from such fantastic images Hawthorne also chooses conventional symbols-the snake or the fire, for example, in which he emphasizes the literal presence of the symbol. He pictures sin as a literal snake: "A man to swallow a small snake-and it to be a symbol of a cherished sin"

15 Hawthorne also uses this expression in "The Old Manse." 
(p. 228); and "persons who have been inoculated with the venom of rattlesnakes," who then take on the serpent's nature (p. 238). Thinking of fire as literally the way to hell, he imagines "wishing to send a letter to a dead man, who may be supposed to have gone to Tophet,- - throw it into the fire." ${ }^{16} \mathrm{He}$ also notes a conventional expression actually come to life: "In the New Statistical Acct. of Scotland . . . it is stated that a child was born, and lived to the age of, I think, two years, with an eye in the back of its head" (American Notebooks, p. 292).

In these passages Hawthorne raises the issue of whether language creates relations between natural and spiritual things or whether it simply reflects relations that, however strange, already exist. Common figures of speech, such as the bosomserpent, the heart of stone, and the girl as poisonous flower, often become the germs of his tales, precisely because they call attention to the relations between literal and figurative meaning. Within the context of theories of language that tie literal to physical and figurative to spiritual, these strange figurative expressions show that, for Hawthorne, language does not always reveal a direct correspondence between nature and spirit or that, if it does, the correspondence can be disturbing in its implications.

Hawthorne also recognizes how perspective complicates relations among nature, spirit, and language. In his Notebooks and in most of his fiction he emphasizes the role of perspective in determining meanings, which are already destabilized by the question of the relations between the literal and the figurative. In an entry in his English Notebooks describing the mountains of Ben Venue and Ben An in Scotland, Hawthorne notes the impossibility of expressing the "whole truth":

I wish I could give an idea of the variety of surface upon one of these hill-sides, so bulging out and hollowed in, so bare where the rock breaks through, so shaggy in other places with heath, and then perhaps a thick umbrage of birch, oak, and ash, ascending from the base high upward. When I think I have described them, I remember quite a different aspect, and find it equally true, and

${ }^{16}$ The English Notebooks, ed. Randall Stewart (New York: Russell and Russell, 1941, 1962), p. $3^{6 .}$ 
yet lacking something to make it the whole or an adequate truth. (p. 524)

In this passage Hawthorne attempts to describe the scene fully and adequately but acknowledges that he cannot. He first offers two oppositions: "bulging" and "hollowed," "bare" and "shaggy." Then he adds a fifth aspect, the "thick umbrage" of trees, similar to "shaggy" heath in that both are vegetation as opposed to bare rock, but set off from the two oppositions by the phrase "and then perhaps," which indicates that he has remembered this last aspect of the scene but may not be quite sure where it fits in. Hawthorne inserts the "thick umbrage" of trees into his description of the opposing aspects of the scene as an intrusion of yet another aspect into his desire to order the scene in his mind. But the description indicates that the truth cannot be "seen" all at once; he cannot hold the whole truth of the mountainside in his mind at one time, nor can he describe it in words that would "give an idea of the variety of surface upon one of these hill-sides."

In another passage from his American Notebooks Hawthorne develops a theory of the relation between literal and figurative meaning as a question of perspective:

Letters in the shape of figures of men, \&c. At a distance, the words composed by the letters are alone distinguishable. Close at hand, the figures alone are seen, and not distinguished as letters. Thus things may have a positive, a relative, and a composite meaning. (p. 183)

The "positive" meaning of things is derived from either perspective, near or far, before the observer moves from that perspective. Then, realizing that near and far perspectives yield different "meanings," the observer realizes that the meaning is "relative" to where he or she stands. The "composite" meaning attempts to combine both "positive" and "relative" meanings. That is to say, the observer can see that the "meaning" of the "words" formed by the "letters in the shape of figures of men" is a "composite," made up of the meaning of the words themselves (which is itself problematic), the purely graphic meaning of the individual figures "not distinguished as letters," and the mean- 
ing of the relations between the individual letters figured as men. In this passage Hawthorne indicates that the way we determine the meaning of something changes as our perspectives change. Things accrue meaning over time as we add different perspectives, yet we cannot "hold" all perspectives at once. In addition, one perspective may even block another. ${ }^{17}$

These passages from Hawthorne's Notebooks show him exploring the ways in which physical things might be related to spiritual ideas and how we determine possible meanings of those relations. He finds that language usually does not directly mediate between nature and spirit and that perspective influences to a large degree our determinations of meanings. Much of his fiction explores these same issues.

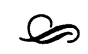

Before the 1980 os most scholars who discussed "Rappaccini's Daughter" tried to find a single consistent interpretation of the story-some saw it as a version of the Fall, or an allegory of science, or an allegory of sexuality. ${ }^{18}$ A number

17 In "Hawthorne's Literal Figures," in Ruined Eden of the Present: Hawthorne, Melville, and Poe: Critical Essays in Honor of Darrell Abel, ed. G. R. Thompson and Virgil L. Lokke (West Lafayette, Ind.: Purdue Univ. Press, 1981), pp. 71-92, Roy R. Male also discusses this passage. He finds it "seminal for interpreting Hawthorne's work because (1) it suggests that our epistemological uncertainty is rooted in the mystery of language; (2) it indicates his characteristic emphasis upon the graphic rather than the phonetic aspects of language; (3) it affirms that words do not have meaning; people, depending upon their perspective, have meanings for words; and (4) it suggests that language has more than two dimensions" (p. 72). In this essay Male describes Hawthorne's attitude toward language using M. H. Abrams's diagram for orienting critical theories, and Male finds Hawthorne's attitude "basically expressive, with heavy emphasis on its graphic dimension" (p. 77). Male does not study Hawthorne's attitude toward language in the context of nineteenth-century language theory.

${ }^{18}$ For a reading of the story as an allegory of science, see Edward $\mathrm{H}$. Rosenberry, "Hawthorne's Allegory of Science: 'Rappaccini's Daughter,' American Literature, $3^{2}$ (1960), 39-46. For readings of the story as a version of the Fall, see Melvin W. Askew, "Hawthorne, the Fall, and the Psychology of Maturity," American Literature, 34 (1962), 335-43; Oliver Evans, "Allegory and Incest in 'Rappaccini's Daughter,' NineteenthCentury Fiction, 19 (1964), 185-95; Alfred J. Kloeckner, "The Flower and the Fountain: Hawthorne's Chief Symbols in 'Rappaccini's Daughter,' "American Literature, $3^{8}$ (1966), 323-36; Gloria Chasson Erlich, "Deadly Innocence: Hawthorne's Dark Women," New England Quarterly, 41 (1968), 163-79; and Sheldon W. Liebman, "Hawthorne and Milton: The Second Fall in 'Rappaccini's Daughter,'" New England Quarterly, 41 (1968), 
of critics have interpreted the story in terms of one or more of its allusions to previous texts: the story of the Garden of Eden in Genesis or in Paradise Lost, Dante's Inferno and The Vita Nuova, the legend of Alexander and the poisonous Indian maiden, the myth of Vertumnus, the legends of Beatrice Cenci and of the Borgias. ${ }^{19}$ All these allusions could be analogues for the story, but because Hawthorne includes so many allusions, none of these earlier texts can be claimed as the key to interpreting the story. Instead, they offer different perspectives on "Rappaccini's Daughter."

521-35. Frederick Crews reads the story as an allegory of sexuality in "Giovanni's Garden," American Quarterly, 16 (1964), 402-18; and Nina Baym calls the story "an allegory of faith, an allegory of science, and an allegory of sex all at once" (The Shape of Hawthorne's Career [Ithaca: Cornell Univ. Press, 1976], p. 107). Kent Bales also interprets the story in terms of the Fall, though he recognizes the reductive tendency of interpretation ("Sexual Exploitation and the Fall from Natural Virtue in Rappaccini's Garden," ESQ 24 [1978], 133-44).

19 In "The Dual Aspects of Evil in 'Rappaccini's Daughter," PMLA, 69 (1954), 99-109, Roy R. Male, Jr. discusses allusions to Dante, Bunyan, Spenser, and Milton; in Dark Conceit: The Making of Allegory (Providence, R.I.: Brown Univ. Press, 1959) Edwin Honig discusses allusions to Vertumnus, Dante, and the Bible (see p. 137). (For other readings in terms of Hawthorne's allusions to Genesis or Milton, see the interpretations of the story as an allegory of the Fall in n. 17.) Robert Daly points to Hawthorne's allusions to Vertumnus, Paradise Lost, and Dante's Divine Comedy, particularly a reference to the Fideist Averroes ("Fideism and the Allusive Mode in 'Rappaccini's Daughter,'" Nineteenth-Century Fiction, 28 [1973], 25-37); Lloyd Spencer Thomas discusses Hawthorne's borrowings from Dante, Ovid, Indian literature, Renaissance iconography, and "oenological and toxicological lore" to "heighten narrative irony" ("'Rappaccini's Daughter': Hawthorne's Distillation of His Sources," ATQ 38 [1978], 177-91 ); David L. Cowles follows the "thread" in the story of the allusions to Dante, not to offer a single reading, which he says would be impossible, but to show more completely how Hawthorne uses Dante in the story ("A Profane Tragedy: Dante in Hawthorne's 'Rappaccini's Daughter," ATQ 6o [1986], 5-24); and Richard Brenzo sees the story as an inversion of the legend of Alexander and the Indian maiden ("Beatrice Rappaccini: A Victim of Male Love and Horror," American Literature, 48 [1976], 152-64). (See also Lloyd Spencer Thomas for a discussion of this legend.) Hawthorne refers to this legend in his American Notebooks: “'A story there passeth of an Indian king that sent unto Alexander a fair woman, fed with aconite and other poisons, with this intent complexionally to destroy him!'-Sir T. Browne" (p. 184). Mary Cappello explores allusions to Cellini's Autobiography (“'Rappaccini’s Daughter' as Translation,” Philological Quarterly, $6_{5}$ [1986], 263-77); Robert Schwartz discusses the relation of the story to a folktale in “'Rappaccini's Daughter' and 'Sir Hugh, or, the Jew's Daughter,' "Western Folklore, 45 (1986), 21-33; and Carol Marie Bensick investigates the story's sixteenth-century Paduan setting and its parallels to the United States in the nineteenth century, discussing the preceding allusions in the process (La Nouvelle Beatrice: Renaissance and Romance in "Rappaccini's Daughter" (New Brunswick, N.J.: Rutgers Univ. Press, 1985). 
Before the advent of post-structuralist theory, critics commonly apologized for their inability to provide a single consistent reading of the story. ${ }^{20}$ More recently critics have tended to assert, rather than apologize for, the indeterminacy of the story. Beverly Haviland has argued that Hawthorne uses allegory to attack Transcendentalism and Romanticism by deconstructing the "hierarchical relation of the ideal and the real" ("The Sin of Synecdoche," p. 279). Deborah L. Jones has claimed that "Rappaccini's Daughter" "provides a model of allegory as it has been described by Paul de Man: Hawthorne's short allegory offers itself as a paradigm of the 'autodeconstructive' narrative"; in other words, the tale tells the story of its own "unreadability" ("Hawthorne's Post-Platonic Paradise," p. 155). Although the story certainly can be used as an example for deconstructionist theory, I would argue that we understand more about its working if we place it within its own historical context, particularly concerning the ways in which the story explores questions raised about relations among language, nature, and spirit discussed by most of those theorists writing about language during Hawthorne's own time.

"Rappaccini's Daughter" traces the intricate connections between the physical and spiritual aspects of our experience. The story shows that one's framework for determining meanings-literal and figurative-of things or events powerfully influences one's view of the relations between the physical and

${ }^{20}$ In $195^{2}$ Richard Harter Fogle wrote: "I have found 'Rappaccini's Daughter' the most difficult of Hawthorne's stories" (Hawthorne's Fictoon: The Light and the Dark [Norman: Univ. of Oklahoma Press, 1952], p. 91); Roy Male claimed in 1954: "Achievement of a fully satisfactory reading is difficult, however, because this is Hawthorne's most complex story" ("Dual Aspects," p. 99). By 1965, Sidney P. Moss argued that "in 'Rappaccini's Daughter' Hawthorne uses ambiguity both as technique and theme" ("A Reading of 'Rappaccini's Daughter,'” Studies in Short Fiction, 2 [1965], 145). In "What Happens in 'Rappaccini's Daughter,' American Literature, 43 (1971), 336-54, Morton L. Ross wrote that "it is by now conventional to introduce a new reading of this story with a formula of apology which alludes to the tale's complexity, nearly despairs of finding consistency, and tacitly admits tightening the knot of allegorical possibilities already attributed to it" (p. 337). In 1976 Nina Baym explained that the story "is susceptible of a number of partial explanations but seems to evade any single wholly satisfactory reading" (The Shape of Hawthorne's Career, p. 107); and by 1986 Mary Cappello argued that "one reason for the abundance of critical discourse generated in response to 'Rappaccini's Daughter' is that the tale is amazingly inclusive, it speaks to a multiplicity of concerns” (“'Rappaccini’s Daughter' as Translation,” p. 263). 
spiritual aspects of experience. For example, according to the "spiritual" view of language as expressed by Emerson in Nature, the literal meaning of a word refers to its physical meaning, and its figurative meaning expresses a corresponding spiritual, moral, or emotional meaning. This is Giovanni's view of the relations between the literal and figurative meanings of poison.

Giovanni believes that poison corresponds to evil and that health and beauty correspond to goodness, so when Beatrice appears to be poisonous he is bewildered by the disjunction between her apparent health and beauty and her apparently poisonous nature. Giovanni's conflicting feelings and his desire to know whether or not Beatrice is poisonous lead him to think in terms of simple oppositions. He wants to know whether Beatrice is an "angel" or a "demon," "beautiful" or "terrible." Giovanni always works within the framework of oppositions he has set up: either Beatrice is poisonous, and therefore evil, or she is purely good and beautiful, and therefore not poisonous. Hawthorne questions this framework. Beatrice is certainly poisonous; the story provides sufficient evidence for this conclusion in the bouquet of flowers that withers in her hand, the lizard and the insect that she poisons with her breath, and Giovanni himself, who becomes poisonous by contact with Beatrice. The story does not support the idea, however, that her poisonous nature corresponds to a poisonous spirit.

The narrator, toward the end of the story, dismisses the literal, physical poison and advocates understanding "truth" by relying on a kind of spiritual intuition. After Giovanni realizes that he has become poisonous and is furious about it, the narrator reports:

there came [to Giovanni] . . . recollections of many a holy and passionate outgush of [Beatrice's] heart, when the pure fountain had been unsealed from its depths, and made visible in its transparency to his mental eye; recollections which, had Giovanni known how to estimate them, would have assured him that all this ugly mystery was but an earthly illusion. (p. 122)

This passage, with its Emersonian echoes of transparent truth, shows the tendency of the Transcendentalist position to favor spiritual over material "facts" and to eliminate the role of language in understanding spiritual truth. 
The story indicates, however, that we cannot ignore the physical poison and focus solely on Beatrice's apparent spiritual purity, because the poison remains literally and dangerously present. An empiricist view of language, like that of A. B. Johnson, also eliminates the role of language in understanding spiritual truth, because for Johnson language is an arbitrary system, "apart from Creation," having no inherent connection to nature or spirit. Of course, an empiricist would never ignore the evidence indicating that Beatrice is poisonous, as the narrator seems to do by the end of the story.

The story indicates the contradictions within the "spiritual view" of the nature of language: on the one hand this view assumes that language reveals the correspondence between nature and spirit; on the other hand it values spirit over nature. If we can understand truth through a spiritual intuition and reject physical experience, then the spiritual and the physical do not necessarily correspond and we do not need language to understand spiritual truth. In fact, language may block understanding by indicating a correspondence between literal and figurative poison that may not exist.

The story, however, does not advocate an empirical view of language, like Johnson's, which holds that language clouds our view of reality so that we should try to understand "Creation" completely apart from the structure of language. Nothing in the story indicates that we could understand "truth" apart from language. In fact, the story questions our ability to verify both empirical and spiritual evidence. The view of the relations among language, nature, and spirit that the story seems finally to support is similar to Bushnell's view.

Bushnell agrees with Johnson that words do not exactly refer to specific physical or mental phenomena, but he also maintains that physical things have a "mysterious correspondence or analogy" to spiritual things, which language reveals in the relation between literal and figurative meanings. Further, he claims that "we never come so near to a truly well rounded view of any truth, as when it is offered paradoxically; that is, under contradictions" (God in Christ, p. 55). The paradox of Beatrice's position as apparently physically poisonous and spiritually pure illustrates Bushnell's idea. The tale's contradictory interpretations of poison as repellent yet alluring and deadly yet invigorating 
are also instances of coming near "to a well rounded view of any truth."

In order to reach a "well rounded view" of truth we must try a number of different perspectives and determine possibilities for meaning by combining the insights gained from different viewpoints, as Hawthorne suggests in his Notebooks entry on the "letters in the shape of figures of men." The characters in "Rappaccini's Daughter," however, seem incapable of combining insights. Giovanni vacillates in his interpretation of the relations between the literal/physical poison and its figurative/ moral meanings; Baglioni derives his interpretation from his perspective as a scientist and as Rappaccini's rival; and the narrator, who seems omniscient, changes his view of Beatrice about halfway through the story. The narrator is also influenced by whatever perspective he takes. At first he seems to sympathize with Giovanni and to distrust Beatrice, accepting the correspondence between poison and evil; then he begins to idealize Beatrice and to complain of Giovanni's shallowness. By the end of the story the narrator puts his faith in spiritual knowledge alone and ignores sensory evidence. Other elements of the story, however, insist on the physical poison, which makes it difficult for the reader easily to move from a literal to a figurative level and thereby to ignore the physical poison. The seemingly omniscient narrator actually only offers another perspective on the events of the story. Just as Hawthorne in his American Notebooks was not able to describe accurately the whole mountainside of Ben Venue or Ben An because the mountain cannot be seen all at once, he shows in "Rappaccini's Daughter" that even a narrator who seems to be omniscient takes a perspective that narrows his view of a complex whole. This conclusion presumes that the "whole story" exists, as the whole mountainside exists, but that no one, neither character, nor narrator, nor reader, nor perhaps author, can know or "see" the "whole story" all at once.

Reading "Rappaccini's Daughter" in the context of midnineteenth-century language theory shows that the story's indeterminacy is a product of the debates of the time about whether and how language connects nature to spirit, thereby revealing "truth." These issues were central to Hawthorne's thinking and writing, as the Notebooks show, and central to a large part of Amer- 
ican writing during the mid nineteenth century. In the story Hawthorne shows the limitations of both spiritual and empirical views of language. The story indicates that Beatrice is good, but she is poisonous as well. This combination is not possible, according to the narrator's and Giovanni's spiritual view of the relations between the literal poison and its possible moral meanings. The empirical view of language is not concerned with correspondences between the literal poison and its possible moral meanings. However, throughout the story the narrator and the characters grapple with questions of whether and how physical facts are connected to spiritual meanings, as did Hawthorne and many of his contemporaries. In the late twentieth century most people accept a view of language similar to the empirical view that relations between signs, signifiers, and referents are arbitrary. This perspective, of course, influences our ways of determining (or not determining) meanings. By understanding the views of language prevalent during Hawthorne's time and reading his writings in the context of these ideas about language, we can arrive at a clearer understanding of the source of Hawthorne's characteristic indeterminacy.

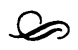

In his passage picturing "letters in the shape of figures of men" Hawthorne shows the difficulty of "taking in the whole view," so to speak, at once. We can take a distant perspective and interpret the shapes as letters forming words but cannot see that the letters also have the shapes of men. Jonathan Arac argues for the value of the distant, or broad, perspective, viewing a text in its historical and political context. We can also look at the shapes closely and see the figures of men in them but not be able to notice that the shapes are also letters, forming words. J. Hillis Miller advocates the near perspective, arguing in fact that the near perspective in a sense subsumes the far, that language surrounds what we might think are the broader perspectives of history. Hawthorne seems to be advocating an awareness of multiple perspectives, even though we may only be able to take one at a time. The "composite" meaning would include all the possibilities for meaning offered by various perspectives. 
Because Hawthorne specifically illustrates the impossibility of a complete perspective, his view reveals the problems with theories that claim to offer a total perspective. Studying the language theories of his contemporaries and his own ideas about language in his Notebooks indicates that the indeterminacy of much of Hawthorne's fiction derives from the uncertainty about relations among nature, spirit, and language during the mid nineteenth century.

University of New Orleans 